\title{
THE DEVELOPMENT OF TEACHING MATERIALS BASED ON LOCAL WISDOM IN JIGSAW LEARNING MODEL FOR DESCRIPTION WRITING SKILLS
}

\section{Krisna Anggraeni, Devi Afriyuni Yonanda}

Universitas Majalengka

krisnaanggraeni24@gmail.com

\section{Article History}

accepted 30/09/2018

approved $12 / 10 / 2018$

published 30/10/2018

\section{Keywords}

teaching materials based on local wisdom, jigsaw learning model, description writing skills

\begin{abstract}
This study aims to find out how to design a teaching materials based on local wisdom in jigsaw learning model for description writing skills. The research method used are"The Research and Development Method of Borg \& Gall". The teaching materials develop six learning meetings based on the analysis of elementary school studentsneed in grade IV in Indramayu. The validation of teaching material product design was carried out by four expert teams as validators which produced a score of $86.45 \%$ with very good assessment criteria. The readability of the book test results by students obtained a score of 89 . The results of the product trials obtained very good criteria, the practicality response of teachers $91.67 \%$ and the practicality response of students $86.57 \%$. The conclusion is, the teaching materials based on local wisdom in jigsaw learning model for description writing skills are valid and practical to use.
\end{abstract}

Social, Humanities, and Education Studies (SHEs): Conference Series https://jurnal.uns.ac.id/shes
p-ISSN 2620-9284

e-ISSN 2620-9292 


\section{PENDAHULUAN}

Peraturan Menteri Pendidikan Nasional Republik Indonesia Nomor 64 Tahun 2013 tentang Standar Isi menjelaskan bahwa bahasa memiliki sentral dalam perkembangan intelektual, sosial dan emosional peserta didik dan merupakan penunjang keberhasilan dalam mempelajari semua bidang studi. Pembelajaran bahasa diharapkan membantu peserta didik mengenal dirinya, budayanya dan budaya orang lain, mengemukakan gagasan dan perasaan, berpartisipasi dalam masyarakat yang menggunakan bahasa tersebut, dan menemukan serta menggunakan kemampuan analisis dan imaginatif yang ada dalam dirinya. Salah satu kemampuan berbahasa tersebut adalah keterampilan menulis deskripsi.

Iskandarwassid dan Sunendar (2011: 248) menjelaskan bahwa menulis adalah keterampilan berbahasa yang paling akhir dikuasai setelah keterampilan mendengarkan, berbicara, dan membaca. Kemampuan menulis membutuhkan kemampuan berbahasa yang bersifat aktif dan produktif. Sokolik mengemukakan bahwa 'writing is a combination of process and product'. Sedangkan Olson berpendapat bahwa 'the concept that writing is a process is very useful to young writers' (Linse, 2005: 98). Berdasarkan dua pendapat tersebut dapat disimpulkan bahwa menulis adalah perpaduan proses dan hasil yang bermakna bagi penulis dan harus diajarkan sedini mungkin.

Graves banyak melakukan penelitian tentang pembelajaran menulis menyampaikan banyak manfaat menulis yaitu menulis mengembangkan kecerdasan, menulis mengembangkan daya inisiatif dan kreatif, menulis mendorong kebiasaan serta memupuk kemampuan dalam menemukan, mengumpulkan, dan mengorganisasikan informasi, dan menulis menumbuhkan kepercayaan diri dan keberanian (Yunus, 2009: 1.4-1.7). Meskipun demikian, pentingnya keterampilan menulis di sekolah dasar belum diimbangi dengan hasil pembelajaran menulis yang baik. Alfianto (2008: 1) menyatakan bahwa minat peserta didik baik yang menyangkut minat menulis, maupun minat untuk mengikuti pelajaran Bahasa Indonesia semakin tampak menurun. Hal ini disebabkan oleh beberapa faktor, yaitu pelajaran bahasa Indonesia dianggap pelajaran yang membosankan, pembelajaran bahasa Indonesia hanya bersifat monoton kurang variasi karena hanya berupa pemberian tugas mengarang/ menulis, pelajaran menulis adalah pelajaran yang dianggap sulit oleh peserta didik, dan pengajaran bahasa Indonesia terlalu kaku dan beracuan untuk mengejar materi saja. Faktor lain penyebab rendahnya keterampilan menulis peserta didik menurut Abidin (2013: 191) adalah kecenderungan guru yang lebih mengutamakan tata bahasa dalam menulis dibanding dengan bagaimana mengemukakan gagasan dalam menulis.

Oleh karena itu, perlu adanya peningkatan kualitas pembelajaran menulis dengan melakukan berbagai cara. Salah satunya dengan mengembangkan bahan ajar dan pemilihan model pembelajaran yang sesuai dengan tahapan pembelajaran menulis.Tujuan dari pengembangan bahan ajar adalah agar bahan ajar yang digunakan oleh peserta didik sesuai dengan kebutuhan dan karakteristik peserta didik. Salah satu cara pengembangan bahan ajar yang sesuai dengan kebutuhan dan karakteristik peserta didik adalah dengan menambahkan kearifan lokal.

Kelebihan dari kearifan lokal yaitu dapat menjadi sarana pembelajaran bagi setiap manusia untuk menjadi orang yang cerdas, pandai, dan bijaksana; kearifan lokal memiliki nilai-nilai positif untuk mentransformasikan kepada peserta didik guna membentuk kepribadian positif (Mulyasa, 2012:2). Hal ini juga sesuai dengan prinsip pembelajaran kurikulum 2013 dalam Permendikbud Nomor 103 Tahun 2014 yang salah satunya adalah pengakuan atas perbedaan individual dan latar belakang budaya peserta didik.

Dalam mengembangkan model pembelajaran salah satu model yang dapat digunakan guru adalah model pembelajaran kooperatif.Silberman (2007: 220) jigsaw 
learning atau belajar jigsaw merupakan teknik yang dipakai secara luas yang memiliki kesamaan dengan teknik "pertukaran dari kelompok ke kelompok" (group-to-group exchange) dengan suatu perbedaan penting: setiap peserta didik mengajarkan sesuatu. Teknik ini tepat digunakan dalam pembelajaran menulis. Peserta didik dapat saling berbagi hasil tulisannya dalam pertukaran grup tersebut.

Penelitian yang relevan terkait kearifan lokal terdapat pada penelitian yang dilakukan oleh (1) Mansur (2011)dengan judul Signifikansi Kurikulum Muatan Lokal Dalam Sistem Pendidikan Sekolah, (2)Saputra(2013) dalam penelitianya 'Enhacing Local Wisdom Through Local Content Of Elementary School In Java, Indonesia' mengemukakan bahwa muatan lokal di sekolah dasar dapat membangun budaya Indonesia dalam pendidikan karakter sejak usia dini, serta membangun potensi daerah yang diperlukan untuk meningkatkan standar hidup, (3) Kesiman dan Agustini (2012) dalam penelitianya 'The Implementation of Hypertext-based Learning Media for a Local Cultural Based Learning' mengemukakan bahwa Hypertext berasis media pembelajaran dan kearifan lokal yang dikembangkan dapat digunakan untuk meningkatkan motivasi dan semangat siswa dalam proses pembelajaran, serta mengembangkan kemampuan peserta didik dalam berinteraksi langsung dengan lingkungan.

Berdasarkan pemaparan tersebut maka peneliti akan melakukan penelitian dan pengembangan bahan ajar berbasis kearifan lokal dalam model pengembangan teknik jigsaw untuk keterampilan menulis deskripsi. Rumusan masalah penelitian adalah 'bagaimana desain produk bahan ajar berbasis kearifan lokal dalam model pembelajaran teknik jigsaw untuk keterampilan menulis deskripsi pada siswa kelas IV di Indramayu?' dengan tujuan penelitian untuk memaparkan desain produk bahan ajar berbasis kearifan lokal dalam model pembelajaran teknik jigsaw untuk keterampilan menulis deskripsi pada siswa kelas IV di Indramayu.

\section{METODE}

Pengembangan produk bahan ajar berbasis kearifan lokal dalam metode pembelajaran teknik jigsaw untuk keterampilan menulis deskripsipada siswa sekolah dasar kelas IV didasarkan pada desain penelitian dan pengembangan modifikasi dari prosedur Borg \& Gall.Data penelitian dapat berupa data kuantitatif dan kualitatif. Data kuantitatif adalah data yang diperoleh dari skor tiap analisis data seperti uji validitas dan uji kepraktisan. Data kualitatif adalah data yang diperoleh dari hasil wawancara guru dan siswa.

Teknik pengumpulan menggunakan angket, tes, wawancara dan dokumentasi. Alat pengumpul data yang digunakan untuk angket berupa angket analisis kebutuhan, angket validitas produk, angket uji kepraktisan guru dan siswa. Tes yang digunakan adalah tes uji keterbacaan wacana dengan mengisi kalimat rumpang. Wawancara dilakukan pada guru dan siswa baik pada awal penelitian untuk menganalisis kebutuhan dan pada akhir untuk mengevaluasi produk bahan ajar. Dokumentasi berupa foto dan dokumen pendukung untuk memberikan gambaran penggunaan produk bahan ajar.

Teknik analisis data yang digunakanadalah analisis deskriptif. Keseluruhan data diklasifikasikan menjadi dua, yaitu data kuantitatif dan kualitatif. Data kualitatif diolah dengan mengelompokkan informasi berupa masukan, saran, tanggapan dan kritik yang terdapat pada instrumen pengumpulan data, sedangkan data kuantitatif diperoleh melalui angket kemudian dijumlahkan atau dikelompokkan sesuai dengan instrumen yang digunakan dalam bentuk deskriptif persentase. 


\section{Hasil Analisis Kebutuhan}

\section{HASIL DAN PEMBAHASAN}

Analisis kebutuhan guru memperhatikan lima aspek penting yaitu (1) aspek kebutuhan materi muatan lokal, (2) aspek kebutuhan penyajian buku berwawasan kearifan lokal, (3) aspek kebahasaan dan ilustrasi pendukung buku berwawasan kearifan lokal, (4) kebutuhan fisik/kegrafikan buku berwawasan kearifan lokal, dan (5) aspek Buku panduan guru. Berdasarkan lima aspek tersebut peneliti memperoleh 30 pernyataan kecenderungan jawaban guru yang persentase jawabannya di atas $60 \%$.

Analisis kebutuhan siswa terhadap bahan ajar mencakup lima aspek, yaitu (1) aspek kebutuhan materi muatan lokal, (2) kebutuhan muatan kearifan lokal, (3) aspek kebutuhan penyajian buku berwawasan kearifan lokal, (4) aspek kebahasaan dan ilustrasi pendukung buku berwawasan kearifan lokal, dan (5) kebutuhan fisik/kegrafikan buku berwawasan kearifan lokal. Berdasarkan lima aspek tersebut peneliti memperoleh dua puluh pernyataan kecenderungan jawaban siswa yang persentase jawabannya di atas $60 \%$. Hasil analisis kebutuhan berupa tigapuluh kecenderungan jawaban guru dan dua puluh kecenderungan jawaban siswa yang menjadi dasar peneliti dalam menyusun produk bahan ajar.

\section{Desain Produk Awal}

Berdasarkan hasil analisis kebutuhan, maka selanjutnya disusunlah desain awal produk bahan ajar. Berikut ini peneliti sajikan contoh desain awal produk.

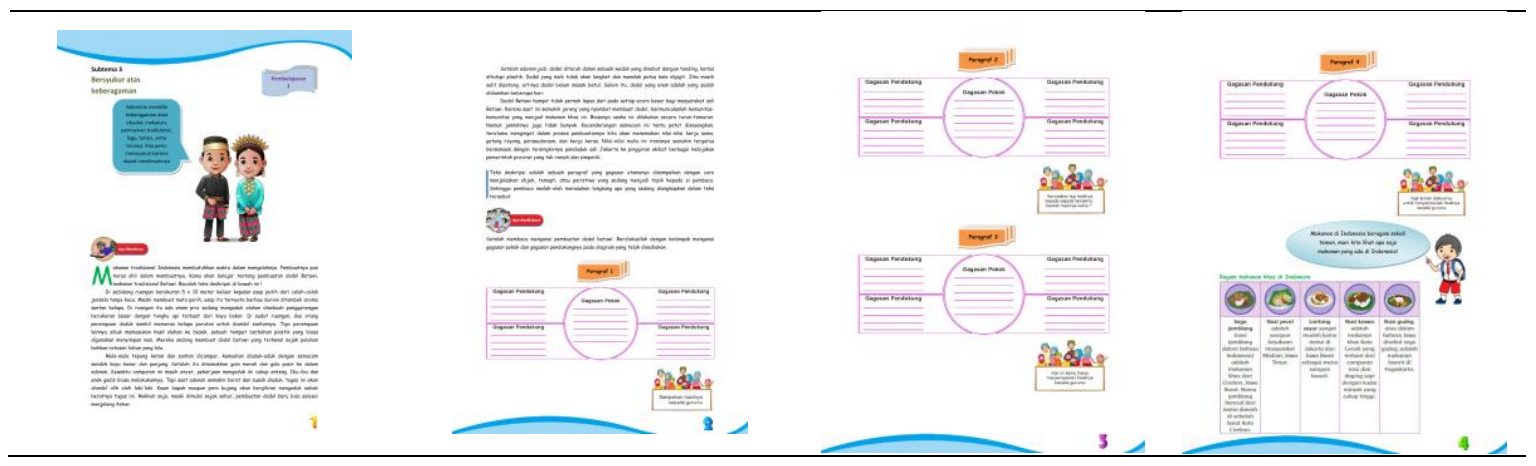

\section{Gambar 1. Contoh Desain Awal Produk Bahan Ajar}

\section{Hasil Uji Validitas dan Uji Kepraktisan}

Uji validasi dilakukan dengan validasi desain. Menurut Emzir (dalam Fatimah, 2017) validasi desain merupakan proses penilaian rancangan produk yang dilakukan dengan memberikan penilaian berdasarkan pemikiran rasional, tanpa uji coba lapangan.Uji validasi bahan ajar melibatkan tiga ahli yakni Supali Kasim, M. Pd (ahli 1), Drs. MS Mustofa, MA (ahli 2), Dr. Sunarto, M. Hum (ahli 3) dan satu praktisi yaitu Entin, S. Pd. Hasil penilaian validator dapat dilihat pada Tabel 1.

Selain validasi ahli, peneliti juga melakukan uji keterbacaan bahan ajar yang dilakukan pada siswa kelas IV SDN Kapringan 1 Indramayu. Hasil tes menunjukkan bahwa keterbacaan pada buku ajar ini mudah dipahami dengan rata-rata nilai siswa adalah 89. Dengan demikian, bahan ajar dinyatakan dapat digunakan dengan kriteria keterbacaan mudah.

Uji kepraktisan respon guru didasarkan pada delapan aspek yaitu sampul buku, anatomi buku, judul buku, menu tambahan, soal dan latihan, kelayakan isi, kebahasaan, dan penyajian. Berdasarkan hasil angket respon gurudisimpulkan bahwa respon guru sangat praktis dengan persentase 91,67\%. Uji kepraktisan juga memperhatikan respon siswa, dilakukan dengan memberikan angket kepada siswa kelas IV SDN Kapringan 1 Indramayu mengambil sampel 18 siswa. Lembar angket 
berisi 15 butir komponen mewakili tujuh aspek yaitu sampul buku, judul buku, menu tambahan, soal dan latihan, kelayakan isi, kebahasaan, penyajian. Berdasarkan hasil analisis angket ditemukan bahwa respons siswa terhadap bahan ajar sangat praktis dengan persentase $86,57 \%$.

\section{Tabel 1. Rekapitulasi Hasil Penilaian Validator terhadap Bahan Ajar}

\begin{tabular}{clcc}
\hline No. & \multicolumn{1}{c}{ Aspek } & Skor & Kategori \\
\hline 1. & Sampul Buku & $96,87 \%$ & Sangat valid \\
2. & Anatomi Buku & $87,50 \%$ & Sangat valid \\
3. Judul Buku & $84,38 \%$ & Sangat valid \\
4. Isi & $85,98 \%$ & Sangat valid \\
5. Menu Tambahan & $75,00 \%$ & Valid \\
6. Soal dan Latihan & $87,50 \%$ & Sangat valid \\
7. Kelayakan isi & $85,98 \%$ & Sangat valid \\
8. Kebahasaan & $83,75 \%$ & Sangat valid \\
9. Penyajian & $83,75 \%$ & Sangat valid \\
10. Kegrafikan & $93,75 \%$ & Sangat valid \\
Rata-Rata & $86,45 \%$ & \\
Kesimpulan & & Sangat Valid \\
\hline
\end{tabular}

\section{Produk Akhir}

Pada tahap akhir pengembangan produk, peneliti melakukan revisi akhir sesuai hasil uji validitas dan uji kepraktisan dengan memperhatikan pula hasil wawancara. Berikut ini peneliti sajikan contoh produk akhir bahan ajar.

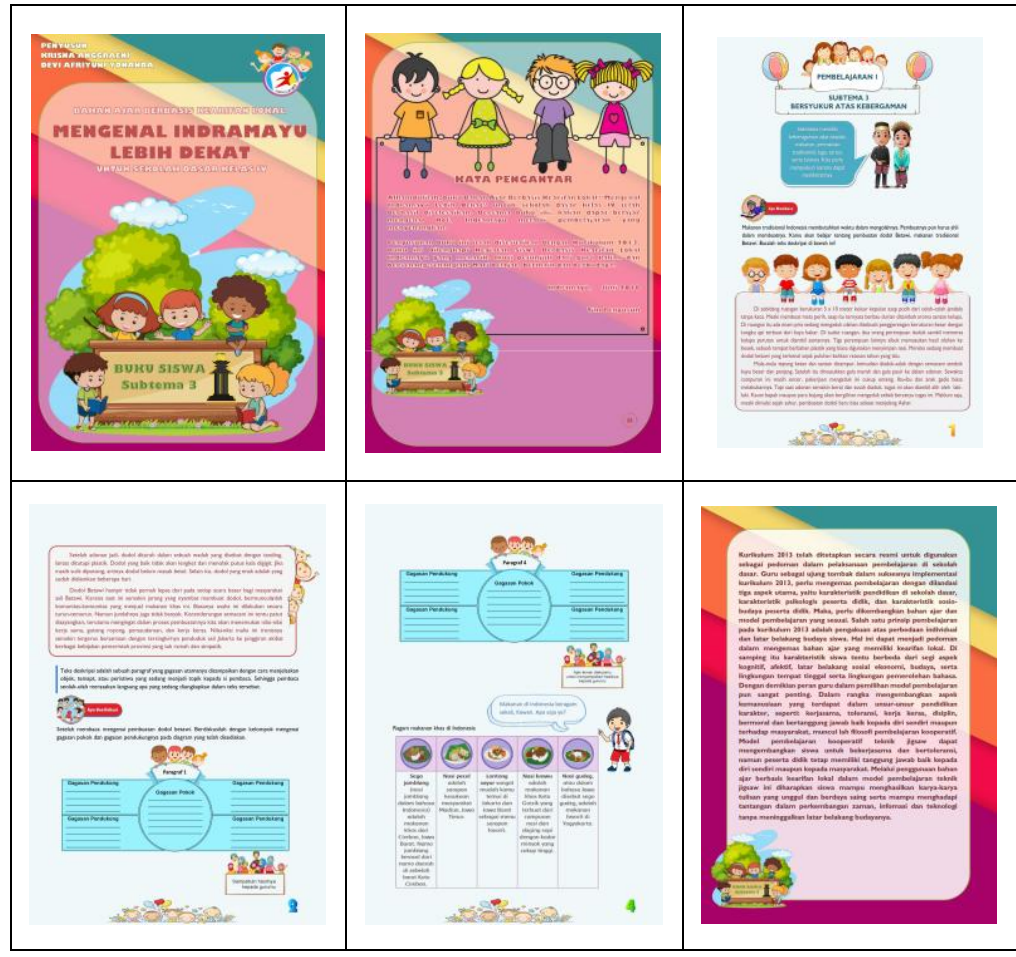

Gambar 2. Contoh Desain Produk Akhir Bahan Ajar 


\section{SIMPULAN}

Penelitian dan pengembangan ini menghasilkan desain produk bahan ajar berbasis kearifan lokal dalam model pembelajaran teknik jigsaw untuk keterampilan menulis deskripsi yang telah valid dan praktis digunakan. Hasil uji validasi ahli yaitu $86,45 \%$ dengan kategori sangat valid. Hasil uji keterbacaan wacana 89. Hasil uji kepraktisan respon guru sangat praktis dengan persentase $91,67 \%$ sedangkan respons siswa terhadap bahan ajar sangat praktis dengan persentase $86,57 \%$.

\section{DAFTAR PUSTAKA}

Abidin, Y. (2013). Pembelajaran Bahasa Berbasis Pendidikan Karakter. Bandung: Refika Aditama.

Alfianto. (2008, Maret 16). Pelajaran Bahasa Indonesia untuk Sekolah Dasar. Diakses dari http://id.forum.wordpress.com/topic/pelajaran-bahasa-indonesia.co.id

Fatimah, N. (2017). Pengembangan Buku Cerita Rakyat BIMA Berbasis Kearifan Lokal (Sebagai Penunjang Gerakan Literasi). Jurnal NOSI, 5 (3) 266-282.

Iskandarwassid \& Sunendar, D. (2011). Strategi Pembelajaran Bahasa. Bandung: Rosdakarya.

Kesiman, Made W. A. 2012. "The Implementation of Hypertext-based Learning Media for a Local Cultural Based Learning". Journal of Information Technology Education: Innovations in Practice, Volume 11.

Kementrian Pendidikan dan Kebudayaan RI. (2013). Peraturan Menteri Pendidikan Nasional Nomor 64 Tahun 2013 tentang Standar Isi Pendidikan Dasar dan Menengah. Jakarta: Penulis.

Kementrian Pendidikan dan Kebudayaan RI. (2014). Peraturan Menteri Pendidikan dan Kebudayaan Republik Indonesia Nomor 103 Tahun 2014 tentang Prinsip Pembelajaran Kurikulum 2013. Jakarta: Penulis.

Linse, C. T. (2005). Practical English Language Teaching Young Learners. New York: McGraw Hill.

Mansur, N. 2011. Signifikansi Kurikulum Muatan Lokal Dalam Sistem Pendidikan Sekolah. Jurnal IImiah DIDAKTIKA. 11 (2), 239-250.

Saputra, G.A.S. 2013. "Enhacing Local Wisdom Through Local Content of Elementary School In Java, Indonesia". Proceeding of the Global Summit on Education. Kuala Lumpur 11-12 March 2013.

Silberman, M.L. diterjemahkan oleh Sarjuli dkk. (2007). Active Learning:101 Strategi Pembelajaran Aktif. Yogyakarta: YAPPENDIS.

Yunus M, dkk. (2009). Menulis 1. Jakarta: Universitas Terbuka 